\title{
Article \\ Fouling Mitigation of Ion Exchange Membranes in Energy Conversion Devices
}

\author{
Beom-Seok Kim ${ }^{1}$ and Jin-Soo Park ${ }^{1,2, *(D)}$ \\ 1 Department of Green Chemical Engineering, College of Engineering, Sangmyung University, \\ Cheonan 31066, Korea; kbs8762@gmail.com \\ 2 Future Environment and Energy Research Institute, Sangmyung University, Cheonan 31066, Korea \\ * Correspondence: energy@smu.ac.kr; Tel.: +82-41-550-5315
}

check for

updates

Citation: Kim, B.-S.; Park, J.-S.

Fouling Mitigation of Ion Exchange Membranes in Energy Conversion

Devices. Energies 2022, 15, 149.

https://doi.org/10.3390/en15010149

Academic Editor: Antonino S. Aricò

Received: 27 November 2021

Accepted: 24 December 2021

Published: 27 December 2021

Publisher's Note: MDPI stays neutral with regard to jurisdictional claims in published maps and institutional affiliations.

Copyright: (c) 2021 by the authors. Licensee MDPI, Basel, Switzerland. This article is an open access article distributed under the terms and conditions of the Creative Commons Attribution (CC BY) license (https:// creativecommons.org/licenses/by/ $4.0 /)$.

\begin{abstract}
In this study, three different environmentally friendly fouling mitigation technologies are suggested and are investigated in reverse electrodialysis (RED) to develop the most appropriate fouling mitigation technology for RED: applying direct current, flowing a solution with high salt concentration, and periodically switching river and seawater streams in RED. The quantitative level of anion exchange membrane fouling mitigation is evaluated in terms of the power density and the amount of power generation of RED. Applying a direct current electric field with higher voltage than $8 \mathrm{~V}$ was not allowed for fouling mitigation in the two-cell-pair bench RED stack due to decomposition of the redox couple. In comparison of the RED operations with two different fouling mitigation methods using firstly 40-min power generation during in-operation and 40-min fouling mitigation stage during out-of-operation as a cycle for $80 \mathrm{~min}$ and secondly 80-min forward power generation and 80-min backward power generation as two cycles. It was found that, over five cycles, the amount of the RED power generation using the former fouling mitigation method is 1.7 times higher than RED power generation using the latter fouling mitigation method.
\end{abstract}

Keywords: ion exchange membrane; energy conversion; fouling; fouling mitigation

\section{Introduction}

Energy conversion devices being developed recently require polymeric electrolytes for ion conduction [1-13], which are generally called ion-exchange membranes (IEMs). IEMs have a special property to exclude coions which have the same charge to covalently fixed functional groups such as sulfonic acid groups for cation exchange membranes (CEMs) or quaternary ammonium groups for anion exchange membranes (AEMs). In contrast to energy conversion devices such as polymer electrolyte fuel cells, water electrolyzers, or redox flow batteries, fouling of IEMs is inevitable in reverse electrodialysis (RED) supplying natural resources, i.e., seawater and river water [14]. IEM fouling occurs by organic, biological, inorganic matters in the natural resources. It has been reported that the main fouling mechanisms were the deposition on the surface and/or the intercalation in the polymeric matrix and the fouling of IEMs causing an increase in electrical resistance and/or the change of $\mathrm{pH}$ [14-19]. There is no complete removal of all possible foulants from the natural resources by pretreatment processes wherein fouling of IEMs is unavoidable. Thus, mitigation of fouling of IEMs is primarily crucial for prolong operation of RED. Recently, C. Li et al. have reported the review on membrane fouling mitigation by coupling applied electric field in membrane system [20]. Applying electric field to relieve membrane fouling was introduced as one of environmentally friendly mitigation technologies. It might potentially detach loosely attached foulants on the surface of IEMs. H.-J. Lee et al. have developed a similar fouling mitigation technology using pulsed electric field to retard membrane fouling by charged organic matters $[16,21]$. J.-S. Park et al. have also reported a zeta potential control technology to remove potential charged foulants in feed streams, which is also another non-harmful mitigation technology [18]. From this point 
of view, the recent emerging energy conversion technology, RED, demands efficient and environmentally friendly fouling mitigation methods to achieve prolong operation without sudden performance drop.

RED uses the cell configuration to separate two main streams by alternately assembled CEMs and AEMs to provide permselective ion transports of cations and anions through CEMs and AEMs, respectively [6,8], along with the reversible redox couple such as ferri/ferrocyanide $\left(\mathrm{Fe}(\mathrm{CN})_{6}{ }^{3-} / \mathrm{Fe}(\mathrm{CN})_{6}{ }^{4-}\right)$ in an electrode stream. As mentioned, membrane fouling is unavoidable problems to result in a decrease in harvesting electrical energy due to an increase in electrical resistance of IEMs which is generally caused by the interaction with non-charged and charged inorganic/organic matters [15-18,21-23]. Recently, T. Rijnaarts et al. have summarized the challenges occurred by the use of real natural water sources in RED, such as the effect of divalent ions [15,24-26], spacer fouling $[27,28]$, and membrane fouling $[28,29]$. Those challenges are mainly due to fouling by inorganics, inorganic and/or organics, and organics, respectively. Even though the presence of divalent ions has been reported to cause the RED performance loss [15], IEMs obviously suffer from fouling by various organic matters. A recent study has reported that charged organic matters supplied into river streams substantially caused the greater fouling in RED than those supplied into seawater streams [30]. Electrostatic attraction was suggested as a main fouling mechanism. In addition, less fouling tendency by charged organic matters in seawater streams was revealed by a decrease in zeta potential of the seawater streams containing charged organic matters by weakening net electrostatic attractions between charged foulants and functional groups of AEMs or CEMs. It proposed that washing by solutions with high salt concentration might mitigate IEM fouling. Thus, it could also be used as environmentally friendly fouling mitigation technology.

In this study, several environmentally friendly fouling mitigation technologies are suggested and are investigated in RED to develop the most appropriate fouling mitigation technology for RED. Applying direct current, flowing a solution with high salt concentration, and switching river and seawater streams in RED are used as environmentally friendly fouling mitigation technologies. For the evaluation of the level of fouling mitigation, power density of RED is mainly measured and compared.

\section{Materials and Methods}

CEMs and AEMs were supplied from Fujifilm (Fujifilm Manufacturing Europe B.V., Tilburg, The Netherlands). The specific properties are summarized in Table 1. All the membranes were equilibrated in either $0.513 \mathrm{M} \mathrm{NaCl}$ for 7 days, and fouled AEMs were prepared by storing in $0.513 \mathrm{M} \mathrm{NaCl}+0.5 \mathrm{wt} \%$ humic acid (Humic acid technical, SigmaAldrich, St. Louis, MO, USA) for 7 days prior to use.

Table 1. Properties of ion-exchange membranes used in reverse electrodialysis [30].

\begin{tabular}{lcc}
\hline \multicolumn{1}{c}{ Fujifilm Membranes } & AEM (Type 1) & CEM (Type 10) \\
\hline Type & anion permselective & cation permselective \\
Reinforcement & polyolefin & polyolefin \\
Thickness $(\mu \mathrm{m})$ & 125 & 135 \\
Resistance ${ }^{1}\left(\Omega-\mathrm{cm}^{2}\right)$ & 1.3 & 2.0 \\
Permselectivity ${ }^{2}(-)$ & 92 & 99 \\
Water permeation $\left(\mathrm{mL} \mathrm{bar}^{-1} \mathrm{~m}^{-2} \mathrm{~h}^{-1}\right)$ & 14 & 6.5 \\
Burst strength $\left(\mathrm{kg} \mathrm{cm}^{-2}\right)$ & 2.4 & 2.8 \\
pH stability & pH $2-10$ & pH $1-13$ \\
Temperature stability $\left({ }^{\circ} \mathrm{C}\right)$ & - & 60 \\
\hline
\end{tabular}

${ }^{1}$ Measured at $0.5 \mathrm{M} \mathrm{NaCl} .{ }^{2}$ Measured at $0.05-0.5 \mathrm{M} \mathrm{NaCl}$.

A bench-scale RED stack with two cell pairs (three CEMs and two AEMs) was used at room temperature $\left(22 \pm 2{ }^{\circ} \mathrm{C}\right)$. Polytetrafluoroethylene (PTFE) gaskets of 0.1 and $1.0 \mathrm{~mm}$ thickness were mounted between the IEMs and between the outmost IEMs and electrode compartments, respectively, along with mesh-type spacers of $0.1 \mathrm{~mm}$ thickness. A pair of 
$50 \mathrm{~mm}$ diameter Pt-coated titanium mesh electrodes (Sung Wing Technology Co., Hong Kong, China) were used in a bench-scale RED stack.

Two main solutions and one electrode solution were supplied to the 2-cell-pair benchscale RED stack. Two synthetic feed solutions were seawater with $0.513 \mathrm{M} \mathrm{NaCl}$ and river water with either $0.017 \mathrm{M} \mathrm{NaCl}$ or $0.017 \mathrm{M} \mathrm{NaCl}+0.001 \mathrm{wt} \%$ humic acid at $2.5 \mathrm{~mL} \mathrm{~min}^{-1}$. The electrode solution of $0.05 \mathrm{M} \mathrm{K}_{3}\left[\mathrm{Fe}(\mathrm{CN})_{6}\right]$ (Junsei Chemical Co., Tokyo, Japan), $0.05 \mathrm{M}$ $\mathrm{K}_{4}\left[\mathrm{Fe}(\mathrm{CN})_{6}\right]$ (Junsei Chemical Co., Tokyo, Japan) and $1 \mathrm{M} \mathrm{Na}_{2} \mathrm{SO}_{4}$ (Junsei Chemical Co., Tokyo, Japan) was circulated through the RED stack at $50 \mathrm{~mL} \mathrm{~min}^{-1}$.

The procedure for all RED experiments consisted of the following steps: (1) The RED stack was equilibrated and activated with $0.513 \mathrm{M} \mathrm{NaCl}$ and $0.017 \mathrm{M} \mathrm{NaCl}$ for $15 \mathrm{~min}$. (2) Open circuit voltage (OCV) was recorded for $1 \mathrm{~min}$ followed by the power density measurement using a linear sweep voltammetry (LSV) with a scan rate of $40 \mathrm{mV} \mathrm{s}^{-1}$. (3) While all the feed and electrode solutions are flowed to the RED stack, the current and voltage of the bench-scale RED stack were measured. Averaged OCV was obtained using the data measured every three seconds for $1 \mathrm{~min}$, and power density was calculated from the voltage and current obtained from LSV.

Environmentally friendly fouling mitigation technologies were suggested as shown in Figure 1. Applying direct current was carried out by providing direct current from an external power supply (E3640A, Keysight Technologies, Santa Rosa, CA, USA) to make humic acid adsorbed on AEMs facing to river streams to be detached by the direction of direct current. Flowing high concentration of $\mathrm{NaCl}$ in river streams was implemented by supplying $0.513,1.026$, or $2.565 \mathrm{M} \mathrm{NaCl}$ into river streams for $90 \mathrm{~min}$ while the 90 -min-RED operation was stopped. Finally, switching from forward RED and backward RED mode was achieved by frequently switching river and seawater streams in the 2-cell-pair bench-scale RED stack.

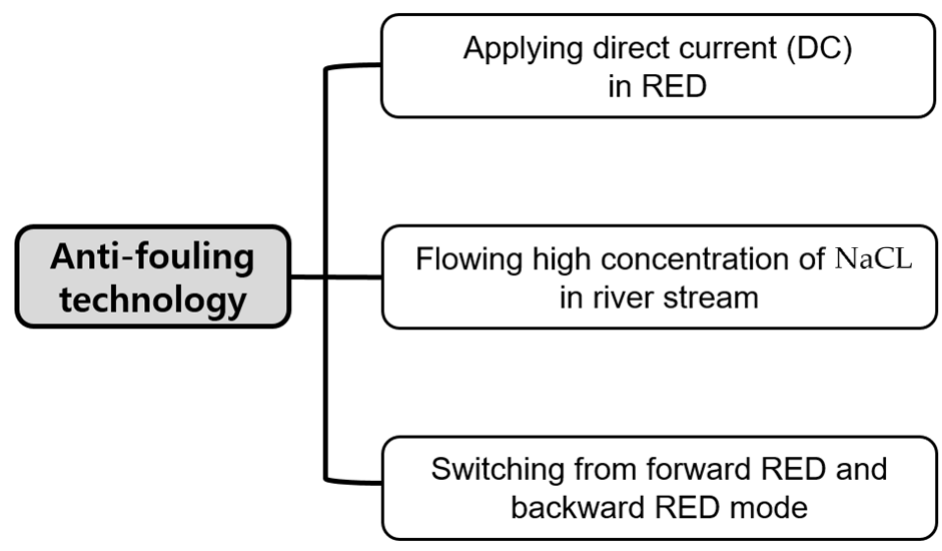

Figure 1. Anti-fouling technology used in this study.

\section{Results}

Applying an DC electric field was used to detach the attached negatively charged humic acid on the surface of AEMs in the river streams in RED as illustrated in Figure 2. It was reported that the DC electric field has been applied in the range of $0.036-30.0 \mathrm{~V}$ for fouling mitigation [20]. In this study, the electrode reactions were carefully observed as the DC electric field increased. As a result, the color change of the electrode solution $(0.05 \mathrm{M}$ $\left.\mathrm{K}_{3}\left[\mathrm{Fe}(\mathrm{CN})_{6}\right]+0.05 \mathrm{M} \mathrm{K}_{4}\left[\mathrm{Fe}(\mathrm{CN})_{6}\right]+1 \mathrm{M} \mathrm{Na}_{2} \mathrm{SO}_{4}\right)$ from yellow to blue was observed the DC electric field greater than $8 \mathrm{~V}$ color as shown in Figure 3. It is due to the decomposition of ferricyanide. The theoretical OCV of one cell in RED supplying $0.513 \mathrm{M} \mathrm{NaCl}$ and $0.017 \mathrm{M} \mathrm{NaCl}$ solutions is approximately $0.175 \mathrm{~V}$ at room temperature, which means that a RED stack with above 46 cell pairs obtains OCV greater than $8 \mathrm{~V}$. Thus, in large-scale RED stacks, the decomposition of the redox couple containing ferricyanide is inevitable. Even though the redox couple is replaced into non-degradable chemicals, huge $\mathrm{pH}$ change causes another problem such as scale formation. Thus, for the use of applying a DC electric 
field, electrode potential should be controlled under the potential of decomposing electrode redox couples used in RED. To evaluate the mitigation of membrane fouling, DC electrode potential of $2.0 \mathrm{~V}$ has been applied, and the power density of the RED stack using fouled AEMs for 0, 60, and 120 min-DC application has been compared. It has been confirmed that no mitigation effect was shown. Thus, it could be concluded that the applying a DC electric field is not appropriate for the mitigation of membrane fouling due to undesirable electrode reaction.

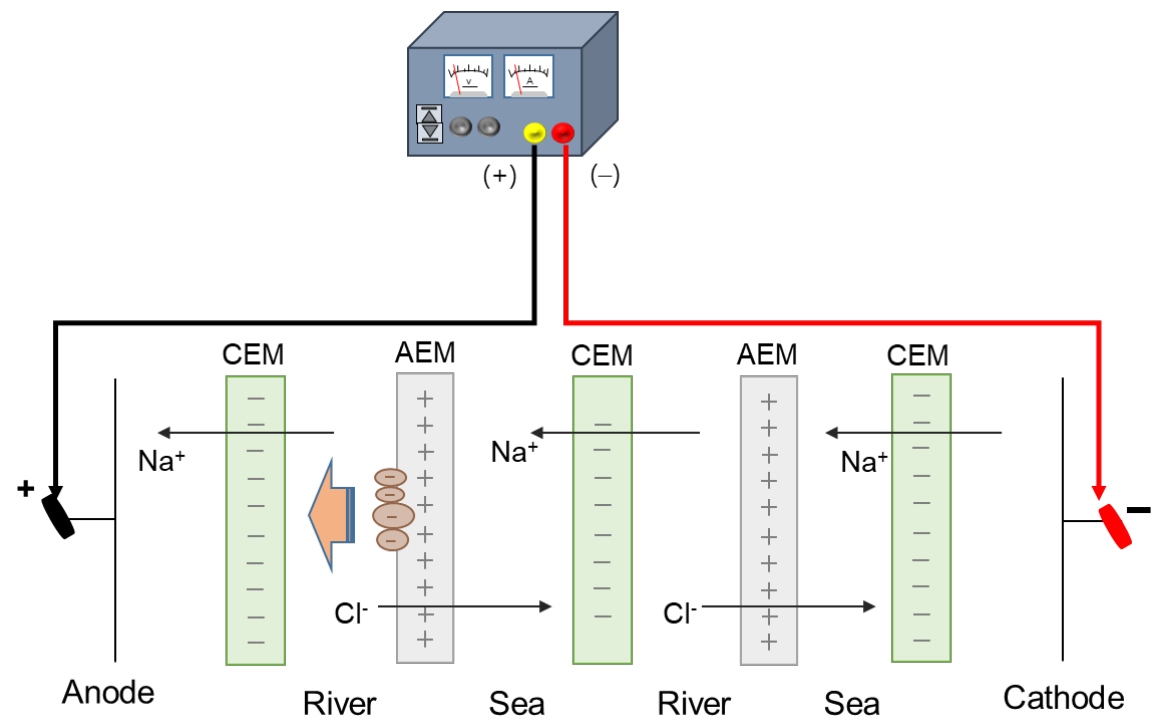

Figure 2. Schematic experimental set-up of applying direct current in reverse electrodialysis.

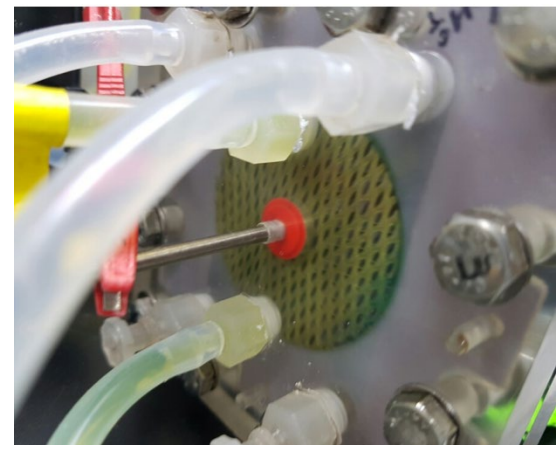

(a)

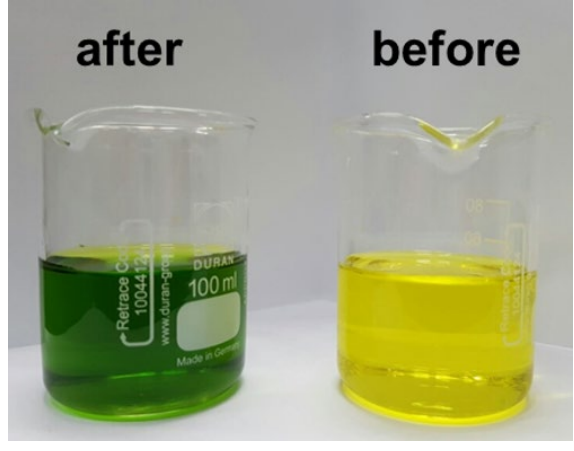

(b)

Figure 3. Pictures of (a) the electrode chamber in the bench-scale RED stack and (b) the electrode solutions before (left) and after (right) the DC electric field of $8 \mathrm{~V}$ is applied.

Secondly, as suggested in the previous study [30], high ionic strength of seawater streams decreases the Debye length of charged organic foulants to result in lower net electrostatic attraction effect and could finally alleviate the fouling tendency to IEMs. Thus, in this study, the regeneration of fouled AEMs is carried out by flowing high concentration salt solutions into river streams where fouling to AEMs mainly occurs. In this study, $0.513,1.026$, or $2.565 \mathrm{M} \mathrm{NaCl}$ are used by supplying into river streams after 90-min-RED operations as illustrated in Figure 4. 


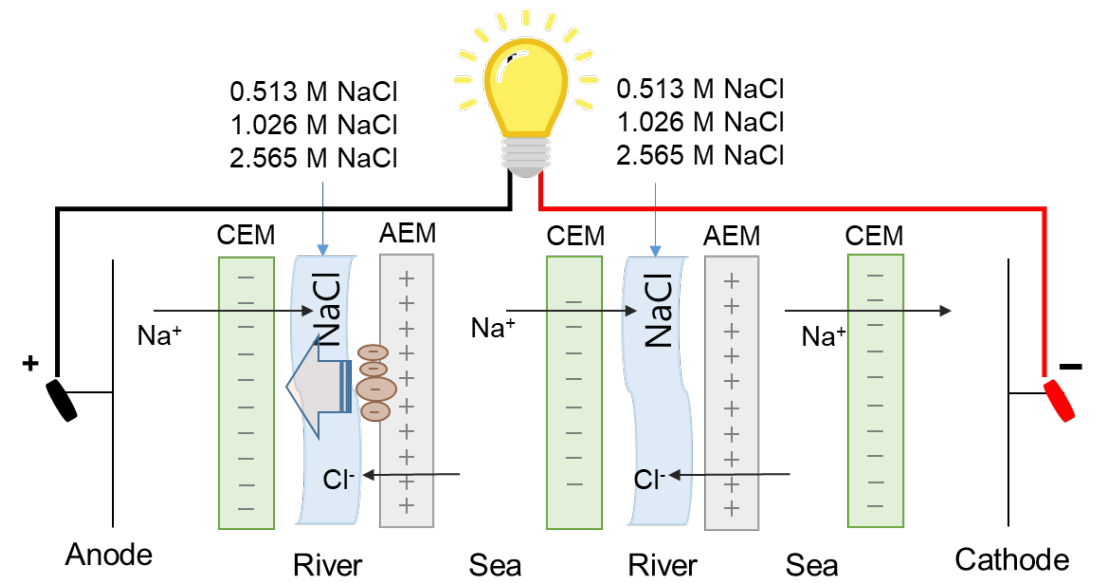

Figure 4. Schematic experimental set-up of applying direct current in reverse electrodialysis.

Figure 5 shows the results of the membrane fouling mitigation using flowing high concentration $\mathrm{NaCl}$ solutions into river streams after 90-min-RED operations. The dashed lines in each graph show the maximum power density of original RED operations in no presence of humic acid as foulant. All the first RED operations have lost $\sim 88 \%$ of the maximum power density after 90-min-RED operations in the presence of humic acid. Afterwards, three regeneration cycles were carried out using different $\mathrm{NaCl}$ concentration solutions. As a result, in case of 0.513 and $2.565 \mathrm{M} \mathrm{NaCl}$ solutions, the recovery of the maximum power density of RED operations gradually decreased as the number of the regeneration cycles increased. However, $1.026 \mathrm{M} \mathrm{NaCl}$ regeneration maintained the similar recovery of the maximum power density of RED operations.
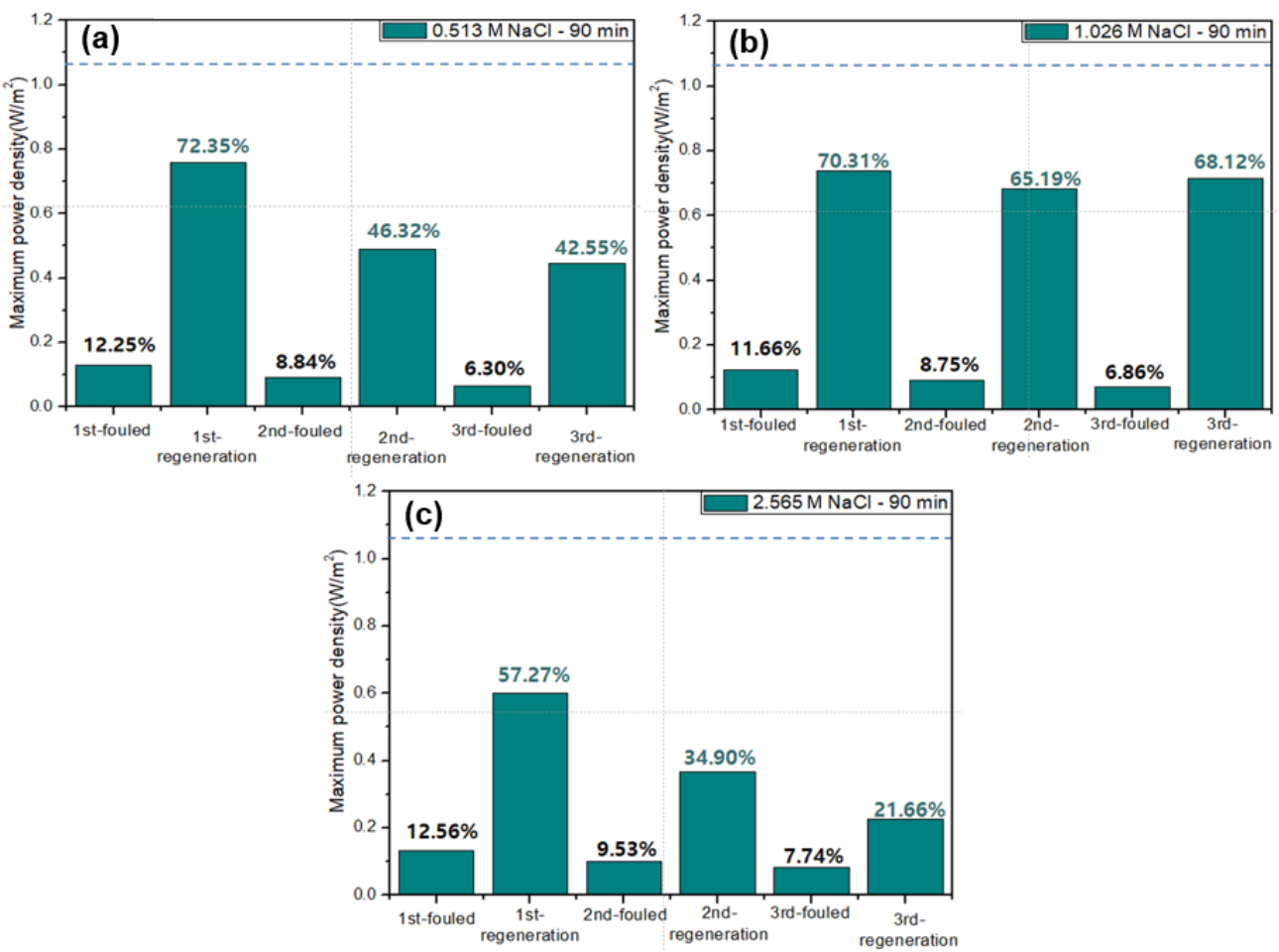

Figure 5. Variation of the maximum power density of the 2-cell-pair bench-scale RED stack operations using $0.513 \mathrm{M} \mathrm{NaCl}$ as seawater and $0.017 \mathrm{M} \mathrm{NaCl}+0.001 \mathrm{wt} \%$ humic acid as river water without and with fouling regeneration using flowing (a) 0.513 , (b) 1.026 , and (c) $2.565 \mathrm{M} \mathrm{NaCl}$ solutions into river streams. The dashed lines in each graph show the maximum power density of original RED operations in no presence of humic acid as foulant. 
Finally, two different modes of RED operation are used as fouling regeneration technique. As illustrated in Figure 6, one RED operation is performed for $90 \mathrm{~min}$ and another RED operation is performed for $90 \mathrm{~min}$ by switching seawater and river streams. Switching two streams could provide the effect of the regeneration by flowing high $\mathrm{NaCl}$ concentration solution as shown in Figure 4. The fouled AEMs facing river streams in the first RED operation (Figure 6a) are able to be regenerated in the second RED operation (Figure $6 \mathrm{~b}$ ) since seawater streams in the second RED operation could be supplied into the river streams of the 2-cell-pair bench-scale RED stack in the first RED operation. In addition, the regeneration using solution-switching maintains the continuous RED operation which keeps power generation, compared to the regeneration using flowing high $\mathrm{NaCl}$ concentration solutions.

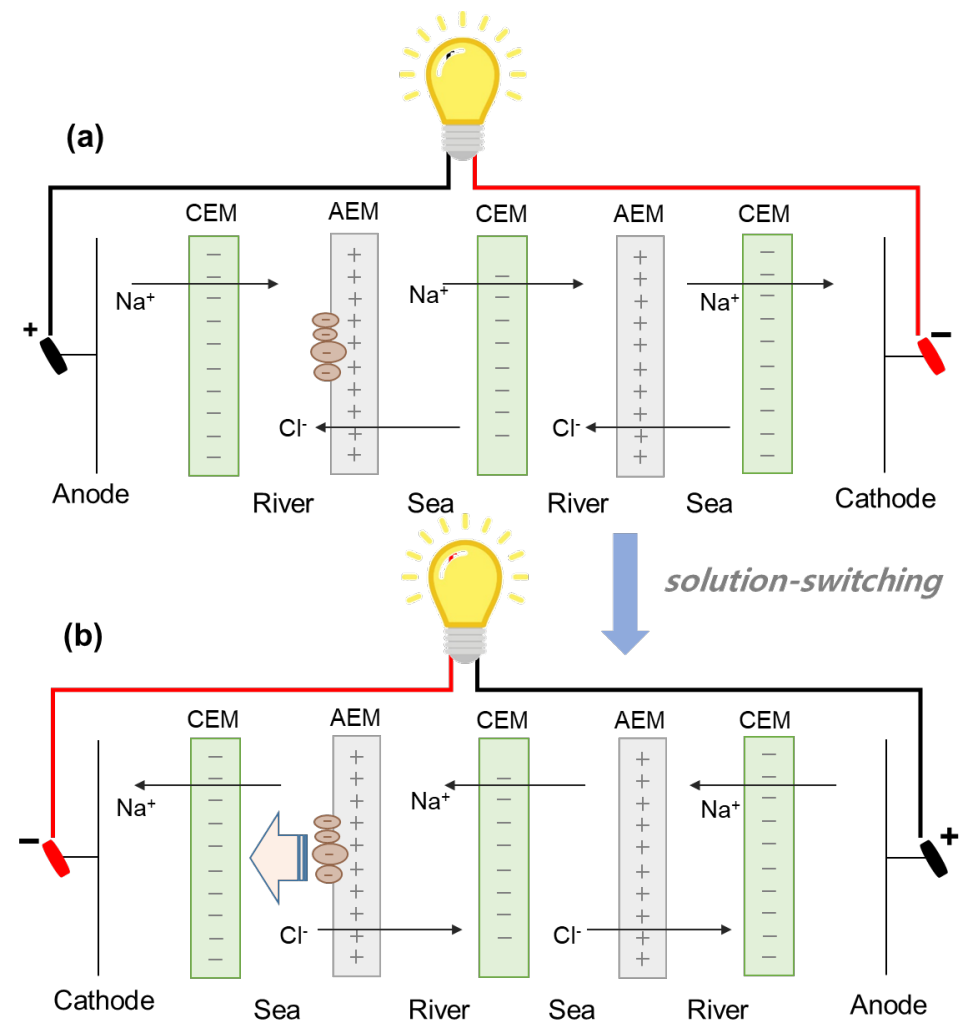

Figure 6. Schematic experimental set-up of solution-switching technique in reverse electrodialysis: (a) the first RED operation and (b) second RED operation.

As a result, Figure 7 shows the result of the regeneration using solution-switching. As explained earlier, the dashed lines in each graph show the maximum power density of original RED operations in no presence of humic acid as foulant. The first RED operations have also lost $\sim 88 \%$ of the maximum power density after 90 -min-RED operations in the presence of humic acid which is in good agreement with Figure 5. The regeneration using solution-switching is to use another RED operation by switching the supply of the solutions-i.e., seawater into river and river into seawater. The regeneration duration of $90 \mathrm{~min}$ was used in the second regeneration method which is the flowing high concentration $\mathrm{NaCl}$ solutions into river streams. In order to apply for the same regeneration duration, 90-min-switched operation duration is, hence, performed in the third regeneration method. To monitor the effect of the third regeneration method, the maximum power density was measured at 20, 40, and 90 min during the 90-min-switched RED operation. As a result, the maximum power density significantly decreases as the switched RED operation time increases. It implies that the third fouling regeneration using solution-switching worsens the AEM fouling. It should be noted that the seawater streams in the first operation mode (see Figure 6a) are switched into the river streams in the second operation mode 
(see Figure 6b). It means that another fouling occurs much more in the switched river streams which are the seawater streams in the first operation mode, rather than the fouling mitigation of the AEMs facing toward the switched seawater streams (originally river streams in the first operation mode).

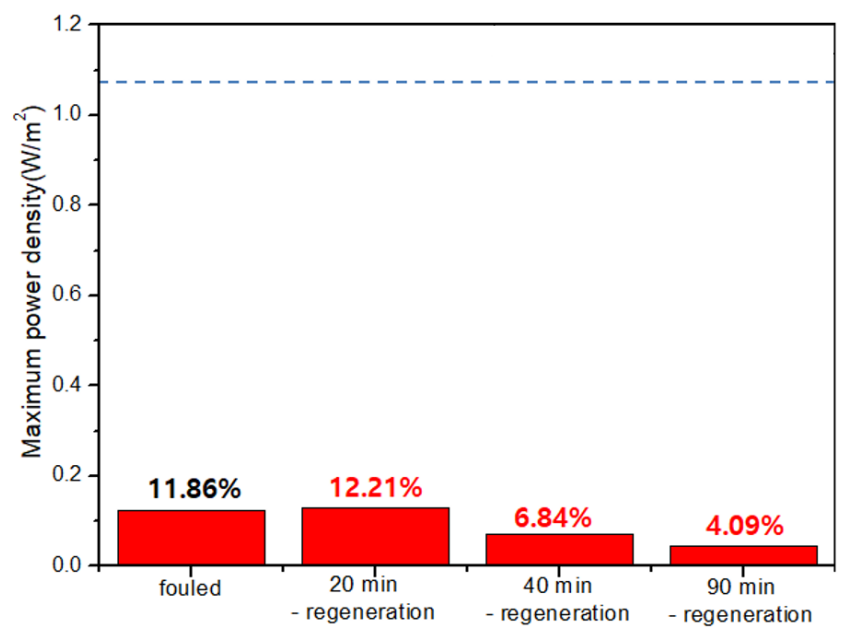

Figure 7. Variation of the maximum power density of the 2-cell-pair bench-scale RED stack operations using $0.513 \mathrm{M} \mathrm{NaCl}$ as seawater and $0.017 \mathrm{M} \mathrm{NaCl}+0.001 \mathrm{wt} \%$ humic acid as river water using solution-switching (operation order: 90-min-RED operation and 20,40, and 90-min-solution-switchedRED operations as accumulated duration). The dashed lines in each graph show the maximum power density of original RED operations with no presence of humic acid as foulant.

\section{Discussion}

In this study, three different mitigation methods of AEM fouling in the 2-cell-pair bench-scale RED stack are investigated: (1) applying a DC electric field to detach the absorbed humic acid on the AEM surface; (2) flowing high concentration $\mathrm{NaCl}$ solutions into river streams in the RED stack; and (3) solution-switching. The first technique is a conventionally used technique in electrodialysis, so called electrodialysis reversal [14]. If the electric field is applied in a direction that allows the loosely adsorbed contaminants to move in the direction of the bulk solution, membrane fouling could be mitigated. Based on the result of previous study [30], the second technique-i.e., flowing high concentration $\mathrm{NaCl}$ to river streams-is newly introduced since high concentration salts weaken the net electrostatic interaction between the absorbed charged foulants and the oppositely charged functional groups of AEMs. In addition, it has been concluded that the zeta potential of the foulants in higher concentration of supporting electrolyte was significantly mitigated since the Debye length of the charge foulants decreased due to the higher ionic strength of seawater streams and causes to lower net electrostatic effect [30]. In other words, when depending on the physciochemical properties of foulants-such as zeta potential, effective radius, diffusion coefficient, and coulomb force-there might be an optimal match of foulants and ionic strength of salt solutions to mitigate membrane fouling. Thus, in this study, $1.026 \mathrm{M} \mathrm{NaCl}$ has obtained the best fouling mitigation as shown in Figure 5. However, the disadvantage of the aforementioned two membrane mitigation technologies is that they can be applied only when the RED operation is stopped. In order to overcome these problems and to use effective membrane fouling mitigation technology, seawater and fresh water in RED were periodically switched as the third technique. Since it is reported that most of the membrane fouling occurs on the surface of the AEMs in the river chamber [30], when the river water is replaced with seawater by solution-switching, the high concentration $\mathrm{NaCl}$ solution flow technique can be applied and then AEM fouling can be alleviated. It is based on the idea that if the river solution is switched again after membrane fouling is alleviated, the previous river chamber enters the seawater again, 
thereby reducing membrane fouling in the chamber. In addition, it is possible to obtain continuous electrical output during these cycles.

As a result, applying a DC electric field with higher voltage than $8 \mathrm{~V}$ was not allowed for fouling mitigation in the 2-cell-pair bench-scale RED stack due to decomposition of the redox couple, $\mathrm{K}_{3}\left[\mathrm{Fe}(\mathrm{CN})_{6}\right] / \mathrm{K}_{4}\left[\mathrm{Fe}(\mathrm{CN})_{6}\right]$. Depending upon the stack configuration, allowable potential where no decomposition of redox couples takes place is, thus, limited to the number of cell pairs in a RED stack which corresponds to power generation. In case of a RED stack using a normal concentration of seawater and river water, the potential of the RED stack with 100 cell pairs shows above $8 \mathrm{~V}$. Thus, this membrane fouling mitigation method cannot be applicable for RED stacks generally using over 1000 cell pairs [31]. Flowing high concentration $\mathrm{NaCl}$ solutions and solution-switching methods are, in principle, based on flowing high concentration $\mathrm{NaCl}$ solutions into river streams where main AEM fouling by negatively charged organic matters occurs. The main difference is that the former and the latter are performed during out-of-operation and in-operation periods, respectively. In addition, in the former, the place where membrane fouling occurs is unchanged, and in the latter, the place where membrane fouling occurs is periodically changed. Figures 5 and 7 seem to reveal that flowing high concentration $\mathrm{NaCl}$ solutions into river streams in the 2-cell-pair bench-scale RED stack mitigate the AEM fouling more effectively than solution-switching. The former, however, has a shorter power generation time than the latter. Therefore, in order to evaluate the quantitative level of membrane fouling mitigation, it is necessary to compare the total amount of electricity produced by the two methods under the same total operation time, including the time of power generation and application of membrane fouling mitigation technology.

Figure 8 shows the amount of power generation obtained from the RED operations using two different membrane fouling mitigation technologies: firstly, 40-min power generation during in-operation and 40-min fouling mitigation stage during out-of-operation as a cycle for $80 \mathrm{~min}$ and secondly, 80-min forward power generation (RED operation as illustrated in Figure 6a) and 80-min backward power generation (RED operation as illustrated in Figure $6 \mathrm{~b}$ ) as two cycles. Over five cycles, the amount of the RED power generation using the former fouling mitigation method is shown to be 1.7 times higher than that using the latter fouling mitigation method. As shown in Figure 5, the $\mathrm{NaCl}$ solution of $1.026 \mathrm{M}$ shows the best membrane fouling mitigation. However, Figure $8 \mathrm{~b}$ is obtained from the membrane fouling mitigation using the $\mathrm{NaCl}$ solution of 0.513 . Thus, it could be concluded that the concentration is not sufficient to mitigate AEM fouling completely. Nevertheless, RED operation using $1.026 \mathrm{M} \mathrm{NaCl}$ as seawater and $0.017 \mathrm{M} \mathrm{NaCl}$ as river water is unrealistic since there is no seawater having $1.026 \mathrm{M} \mathrm{NaCl}$ in nature.

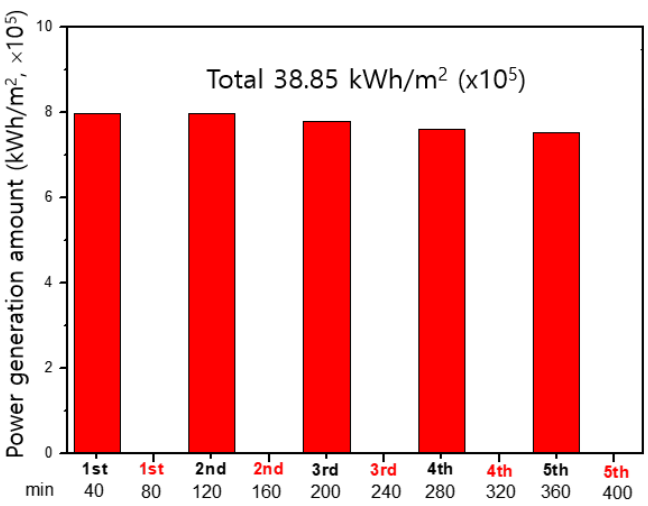

(a)

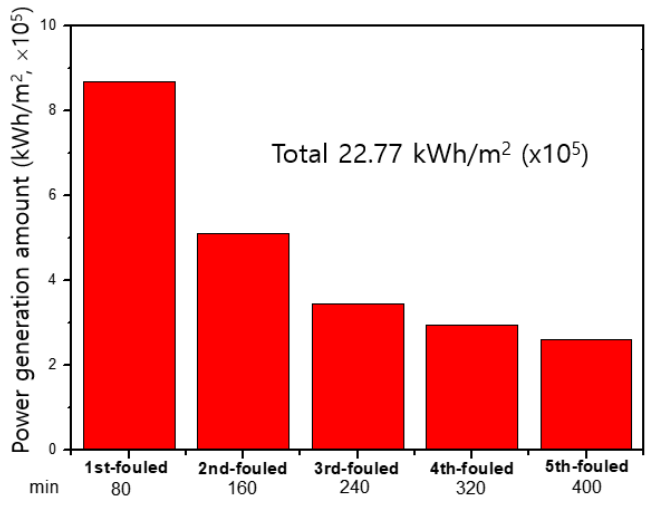

(b)

Figure 8. Comparison of the amount of power generation in $\mathrm{kWh}$ for the RED operations using (a) 40-min power generation and 40-min fouling mitigation stage as a cycle and (b) 80-min forward power generation (Figure 6a) and 80-min backward power generation (Figure 6b) as two cycles. 


\section{Conclusions}

In this study, three different mitigation methods of AEM fouling in the 2-cell-pair bench-scale RED stack using $0.513 \mathrm{M} \mathrm{NaCl}$ as seawater and $0.017 \mathrm{M} \mathrm{NaCl} / 0.001$ wt \% humic acid are investigated: (1) applying a DC electric field to detach the absorbed humic acid on the AEM surface, (2) flowing high concentration $\mathrm{NaCl}$ solutions into river streams in the RED stack, and (3) solution-switching. Based on the previous results that negatively charged foulants in river streams mainly foul the surface of AEMs, humic acid was supplied only in river streams in 2-cell-pair bench-scale RED stack. Applying a direct current electric field with higher voltage than $8 \mathrm{~V}$ was, however, not allowed for fouling mitigation in the 2-cell-pair bench RED stack due to decomposition of the redox couple. Flowing high concentration $\mathrm{NaCl}$ to river streams is newly introduced as a membrane fouling mitigation method. However, the disadvantage of the aforementioned two membrane mitigation technologies is that they can be applied only when the RED operation is stopped. In order to overcome these problems and to use effective membrane fouling mitigation technology, seawater and fresh water in RED were periodically switched. Since most of the membrane fouling occurs on the surface of the AEMs in the river chamber, when the river water is replaced with seawater by solution-switching, the high concentration $\mathrm{NaCl}$ solution flow technique can be applied and then AEM fouling can be alleviated. As a result, flowing a high concentration $\mathrm{NaCl}$ solution into river streams would be the best membrane fouling mitigation technology for the 2-cell-pair bench-scale RED stack supplying $0.513 \mathrm{M} \mathrm{NaCl}$ as seawater and $0.017 \mathrm{M} \mathrm{NaCl} / 0.001 \mathrm{wt} \%$ humic acid. However, if seawater with higher salt concentration could be available for RED operations, the fouling mitigation effect using the solution-switching method should be carefully evaluated, compared to flowing high concentration $\mathrm{NaCl}$ solutions.

Author Contributions: Conceptualization: J.-S.P.; Methodology: B.-S.K. and J.-S.P.; Experimentation: B.-S.K. and J.-S.P.; Validation: J.-S.P.; Investigation: B.-S.K. and J.-S.P.; Resources: J.-S.P.; Writingoriginal draft preparation: B.-S.K. and J.-S.P.; Writing—review and editing: J.-S.P.; Supervision: J.-S.P.; Project administration: J.-S.P.; Funding acquisition: J.-S.P. All authors have read and agreed to the published version of the manuscript.

Funding: This research was funded by a 2019 Research Grant from Sangmyung University.

Institutional Review Board Statement: Not applicable.

Informed Consent Statement: Not applicable.

Data Availability Statement: Not applicable.

Conflicts of Interest: The authors declare no conflict of interest.

\section{References}

1. Park, J.-S.; Shin, M.-S.; Kim, C.-S. Proton exchange membranes for fuel cell operation at low relative humidity and intermediate temperature: An updated review. Curr. Opin. Electrochem. 2017, 5, 43-55. [CrossRef]

2. Park, J.-S. Structure, Synthesis, and General Properties of Ion Exchangers. In Ion Exchange Technology I: Theory and Materials, Ion-Exchange Technology I, 1st ed.; Inamuddin Luqman, M., Ed.; Springer: Berlin/Heidelberg, Germany, 2012; pp. $211-231$. [CrossRef]

3. Park, J.-S. Hydrogen-based energy conversion: Polymer electrolyte fuel cells and electrolysis. Energies 2021, 14, 5068. [CrossRef]

4. Zhang, L.; Chae, S.-R.; Hendren, Z.; Park, J.-S.; Wiesner, M.R. Recent advances in proton exchange membranes for fuel cell applications. Chem. Eng. J. 2012, 204, 87-94. [CrossRef]

5. Song, H.-B.; Park, J.-H.; Park, J.-S.; Kang, M.-S. Pore-filled proton-exchange membranes with fluorinated moiety for fuel cell application. Energies 2021, 14, 4433. [CrossRef]

6. Lee, S.; Shin, M.-S.; Park, J.-S. Anion-conducting pore-filling membranes with optimization of transport number and resistance for reverse electrodialysis. Chem. Lett. 2014, 43, 621-623. [CrossRef]

7. Park, J.-S.; Park, S.-H.; Yim, S.-D.; Yoon, Y.-G.; Lee, W.-Y.; Kim, C.-S. Performance of solid alkaline fuel cells employing anionexchange membranes. J. Power Sources 2008, 178, 620-626. [CrossRef]

8. Oh, Y.; Han, J.-H.; Kim, H.; Jeong, N.; Vermaas, D.A.; Park, J.-S.; Chae, S. Active Control of Irreversible Faradic Reactions to Enhance the Performance of Reverse Electrodialysis for Energy Production from Salinity Gradients. Environ. Sci. Technol. 2021, 55, 11388-11396. [CrossRef] [PubMed] 
9. Park, J.-H.; Shin, M.-S.; Park, J.-S. Effect of dispersing solvents for ionomers on the performance and durability of catalyst layers in proton exchange membrane fuel cells. Electrochim. Acta 2021, 391, 138971. [CrossRef]

10. Lim, S.; Park, J.-S. Composite membranes using hydrophilized porous substrates for hydrogen based energy conversion. Energies 2020, 13, 6101. [CrossRef]

11. Krakhella, K.W.; Morales, M.; Bock, R.; Seland, F.; Burheim, O.S.; Einarsrud, K.E. Electrodialytic energy storage system: Permselectivity, stack measurements and life-cycle analysis. Energies 2020, 13, 1247. [CrossRef]

12. Veerman, J. The effect of the $\mathrm{NaCl}$ bulk concentration on the resistance of ion exchange membranes-measuring and modeling. Energies 2020, 13, 1946. [CrossRef]

13. Clemente, A.; Costa-Castelló, R. Redox flow batteries: A literature review oriented to automatic control. Energies 2020, 13, 4514. [CrossRef]

14. Hansima, M.A.C.K.; Makehelwala, M.; Jinadasa, K.B.S.N.; Wei, Y.; Nanyakkara, K.G.N.; Herath, A.; Weerasooriya, R. Fouling of ion exchange membranes used in the electrodialysis reversal advanced water treatment: A review. Chemoshere 2021, $263,127951$. [CrossRef] [PubMed]

15. Oh, Y.; Jeong, Y.; Han, S.-J.; Kim, C.-S.; Kim, H.; Han, J.-H.; Hwang, K.-S.; Jeong, N.; Park, J.-S.; Chae, S. Effects of divalent cations on electrical membrane resistance in reverse electrodialysis for salinity power generation. Ind. Eng. Chem. Res. 2018, 57, 15803-15810. [CrossRef]

16. Lee, H.-J.; Park, J.-S.; Moon, S.-H. A study on fouling mitigation using pulsing electric fields in electrodialysis of lactate containing BSA. Korean J. Chem. Eng. 2002, 19, 880-887. [CrossRef]

17. Lee, H.-J.; Park, J.-S.; Kang, M.-S.; Moon, S.-H. Effects of silica sol on ion exchange membranes: Electrochemical characterization of anion exchange membranes in electrodialysis of silica sol containing-solutions. Korean J. Chem. Eng. 2003, 20, 889-895. [CrossRef]

18. Park, J.-S.; Lee, H.-J.; Choi, S.-J.; Geckeler, K.E.; Cho, J.; Moon, S.-H. Fouling mitigation of anion exchange membrane by zeta potential control. J. Colloid Interface Sci. 2003, 259, 293-300. [CrossRef]

19. Kozmai, A.; Sarapulova, V.; Sharafan, M.; Melkonian, K.; Rusinova, T.; Kozmai, Y.; Pismenskaya, N.; Dammak, L.; Nikonenko, V. Electrochemical impedance spectroscopy of anion-exchange membrane AMX-Sb fouled by red wine components. Membranes 2021, 11, 2. [CrossRef]

20. Li, C.; Guo, X.; Wang, X.; Fan, S.; Zhou, Q.; Shao, H.; Hu, W.; Li, C.; Tong, L.; Kumar, R.R.; et al. Membrane fouling mitigation by coupling applied electric field in membrane system: Configuration, mechanism and performance. Electrochim. Acta 2018, 287, 124-134. [CrossRef]

21. Park, J.-S.; Lee, H.-J.; Moon, S.-H. Determination of an optimum frequency of square wave power for fouling mitigation in desalting electrodialysis in the presence of humate. Sep. Purif. Technol. 2003, 30, 101-112. [CrossRef]

22. Park, J.-S.; Chilcott, T.C.; Coster, H.G.L.; Moon, S.-H. Characterization of BSA-fouling of ion-exchange membrane systems using a subtraction technique for lumped data. J. Memb. Sci. 2005, 246, 137-144. [CrossRef]

23. Park, J.-S.; Choi, J.-H.; Yeon, K.-H.; Moon, S.-H. An approach to fouling characterization of an ion-exchange membrane using current-voltage relation and electrical impedance spectroscopy. J. Colloid Interface Sci. 2006, 294, 129-138. [CrossRef]

24. Post, J.W.; Hamelers, H.V.M.; Buisman, C.J.N. Influence of multivalent ions on power production from mixing salt and fresh water with a reverse electrodialysis system. J. Memb. Sci. 2009, 330, 65-72. [CrossRef]

25. Vermaas, D.A.; Veerman, J.; Saakes, M.; Nijmeijer, K. Influence of multivalent ions on renewable energy generation in reverse electrodialysis. Energy Environ. Sci. 2014, 7, 1434-1445. [CrossRef]

26. Rijnaarts, T.; Huerta, E.; Van Baak, W.; Nijmeijer, K. Effect of divalent cations on RED performance and cation exchange membrane selection to enhance power densities. Environ. Sci. Technol. 2017, 51, 13028-13035. [CrossRef]

27. Moreno, J.; de Hart, N.; Saakes, M.; Nijmeijer, K. CO2 saturated water as two-phase flow for fouling control in reverse electrodialysis. Water Res. 2017, 125, 23-31. [CrossRef]

28. Vermaas, D.A.; Kunteng, D.; Saakes, M.; Nijmeijer, K. Fouling in reverse electrodialysis under natural conditions. Water Res. 2013, 47, 1289-1298. [CrossRef] [PubMed]

29. Guo, W.; Ngo, H.H.; Li, J. A mini-review on membrane fouling. Bioresour. Technol. 2012, 122, 27-34. [CrossRef] [PubMed]

30. Han, S.-J.; Park, J.-S. Understanding membrane fouling in electrically driven energy conversion devices. Energies 2021, 14, 212. [CrossRef]

31. Nam, J.Y.; Hwang, K.S.; Kim, H.C.; Jeong, H.; Kim, H.; Jwa, E.; Yang, S.; Hwang, K.S.; Kim, H.C.; Jeong, H.; et al. Assessing the behavior of the feed-water constituents of a pilot-scale 1000-cell-pair reverse electrodialysis with seawater and municipal wastewater effluent. Water Res. 2019, 148, 261-271. [CrossRef] 